\title{
AL-AWQAF
}

Jurnal Wakaf dan Ekonomi Islam

Vol. 13, No. 1, Tahun 2020

\section{Analisis Strategi Penghimpunan Wakaf Saham di Indonesia}

\author{
Nurman Hakim ${ }^{1}$ \\ ${ }^{1}$ Universitas Ibn Khaldun, Bogor, nurman.hakim.uika@gmail.com
}

\begin{abstract}
Waqf is potential because the number of Muslims reaches 87 percent of peoples in Indonesia. Share waqf also called stock waqf is one of the productive waqfs in the Islamic stock market but fundraising of share waqf is still low. Their problem is because publication and inclusion level about share waqf is not enough, besides share waqf begins emergence in Indonesia. This research tries to identify important factors and suitable strategies to share waqf's fundraising in Indonesia. The research uses a qualitative approach, which is the SWOT analysis, with an analysis tool is the Analytic Network Process (ANP). The respondent of this research is divided into three categories which is, academia, practice, and regulator. Findings of the research are: first, the importance factor of share waqf's fundraising is an opportunity factor which is the market share of share waqf potentially. The second, suitable strategy is WeaknessOpportunity's strategy which is knowledge improvement for nazhir about share waqf.

Keywords: fundraising, share waqf, SWOT's strategy, ANP.
\end{abstract}

Abstrak: Wakaf secara potensial tercermin dari jumlah muslim yang mencapai 87 persen dari keseluruhan penduduk di Indonesia. Wakaf saham merupakan salah satu wakaf produktif yang terdapat di pasar saham syariah di Indonesia. Namun, realisasi penghimpunan wakaf saham masih relatif kecil karena berbagai kendala seperti sosialisasi dan inklusi mengingat wakaf saham yang relatif baru. Penelitian ini bertujuan untuk mengidentifikasi faktor-faktor yang penting dan strategi yang tepat dalam penghimpunan wakaf saham di Indonesia. Penelitian ini menggunakan pendekatan kualitatif yaitu analisis kekuatan, kelemahan, peluang dan ancaman (SWOT) dengan menggunakan teknik analisis Analytic Network Process (ANP). Responden penelitian ini adalah sembilan orang responden yang terbagi ke dalam tiga kategori yaitu akademisi, praktisi, dan regulator. Hasil penelitian ini adalah, pertama, faktor terpenting dalam penghimpunan wakaf saham yaitu faktor peluang yaitu market share wakaf saham yang potensial. Kedua, strategi yang paling tepat dalam penghimpunan wakaf saham adalah strategi kelemahan-peluang (Weakness-Opportunity) yaitu pembekalan pemahaman nazhir mengenai wakaf saham.

Kata Kunci: penghimpunan, wakaf saham, strategi SWOT, ANP.

$$
\begin{aligned}
& \text { ملخص: الوقف في إندونيسا له إمكانيات عظيمة حيث عدد المسلمين يصل إلى } 87 \text { في المائة من سكانها. } \\
& \text { ووقف الأسهم أحد الأوقاف المنتجة في سوق الأسهم الإسلامية ، لكن الموقوف من الأسهم لا يزال قليلا لما } \\
& \text { واجهه من المشكلات مثل مستوى النشر والتضمين حيث إنه من الأعمال الجديدة في الوقف .يهدف هذا لإلها }
\end{aligned}
$$

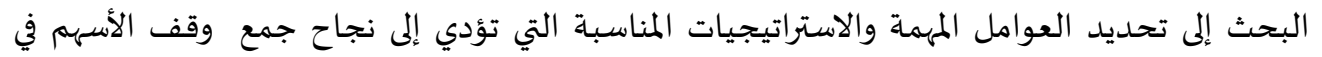




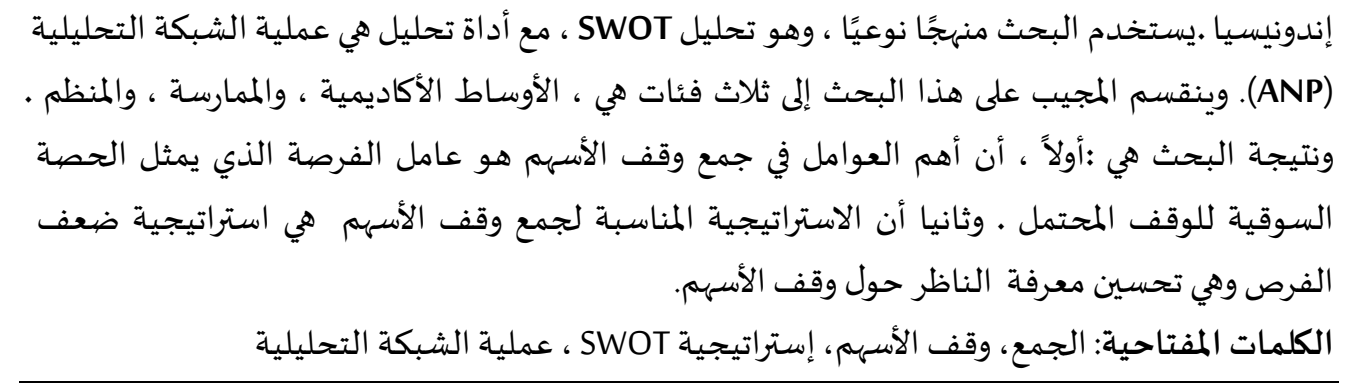

\section{PENDAHULUAN}

Potensi wakaf yang potensial di Indonesia belum dioptimalkan sepenuhnya. Laporan Badan Wakaf Indonesia melaporkan bahwa potensi wakaf di Indonesia saat ini sangat cukup besar mencapai 2000 triliun dengan luas tanah wakaf 420 ribu hektar. Kementerian Agama menerangkan jumlah tanah wakaf mencapai 161.579 hektar. Luas aset wakaf yang tersebar 366.595 lokasi menjadi jumlah harta wakaf terbesar di dunia. Selain wakaf tanah, potensi dana wakaf uang yaitu Rp377 triliun sedangkan yang baru terkumpul baru sekitar Rp199 miliar. Potensi wakaf dari wakif tercermin dari populasi penduduk Muslim Indonesia mencapai 87 persen atau mencapai 270. 625.568 juta jiwa dari keseluruhan menurut Laporan The Future of World Religion tahun 2020.

Sedangkan wakaf sangat berpotensi dalam pembangunan ekonomi khususnya di sejumlah negara dan pengelolaan wakaf yang berhasil telah memberikan manfaat bagi masyarakat (Fuadi 2018). Aspek keberhasilan tersebut dapat tercermin dari aspek produktifitas wakaf, salah satu yaitu wakaf tunai, sebagai instrumen sosial yang meningkatkan kepedulian juga mewujudkan keadilan dan kesejahteraan masyarakat (Rahman 2009). Praktik wakaf saham saat ini di berbagai negara Muslim dan minoritas Muslim merupakan bukti yang baik untuk keberlanjutan peran yang luar biasa lembaga wakaf dari zaman Nabi Muhammad hingga saat ini (Mohsin 2012).

Wakaf saham merupakan pengembangan dari wakaf uang dimana saham yang boleh diwakafkan adalah saham syariah. Saham syariah adalah efek berbasis ekuitas yang memenuhi prinsip Islam. Objek transaksi saham syariah adalah kepemilikan perusahaan yang hanya bisa diterbitkan oleh perusahaan/ koorporasi. Investor melakukan pembelian saham syariah maka investor membeli kepemilikan perusahaan dari pihak lain (Abdulloh 2019). Saham syariah didasarkan pada transaksi-transaksi atas bukan dasar riba seperti suku bunga, transaksi yang meragukan, dan saham perusahaan yang memperniagakan kegiatan yang tidak halal, bebas dari bentuk transaksi yang tidak etis dan tidak bermoral, seperti manipulasi pasar, insider trading (perdagangan orang dalam), penjualan singkat/ penumpukan, dan penggambaran berlebihan tentang posisi keuangan seseorang dengan keterangan yang berlawanan dengan kesepakatan-kesepakatan tanpa dukungan dana yang cukup (Billah 2010).

Wakaf saham atau dikenal juga sebagai wakaf korporasi (corporate waqf) sangat bermanfaat dalam peningkatan perkembangan ekonomi negara dan kesejahteraan masyarakat (Khairi et al. 2015). Model pengelolaan wakaf uang dan wakaf saham sama yaitu mengumpulkan dana untuk kemudian dikonversikan ke dalam bentuk aset tetap atau diinvestasikan ke dalam 
instrumen keuangan. Hanya saja dalam pembahasan wakaf saham, sumber dana wakaf secara spesifik berasal dari saham dan pengelolaannya. Wakaf uang tunai dapat diimplementasikan sebagai reksadana atau dikonversi menjadi aset tetap lainnya. Sedangkan pelaksanaan wakaf saham dapat dilakukan melalui wakaf korporat dan wakaf saham individu (Paksi, Manzilati, and Ekawaty 2018). Saat ini wakaf saham merupakan salah satu bentuk wakaf produktif seperti wakaf tunai juga sebagai salah satu bentuk filantropi Islam di mana investor saham syariah sebagai wakif, Badan Wakaf Indonesia atau Dompet Dhuafa sebagai nazhir, dan saham syariah yang terdaftar di Daftar Efek Syariah sebagai mauqif (Selasi and Muzayyanah 2020).

Implementasi wakaf uang dan saham terhambat oleh pola pikir masyarakat yang masih terpaku pada jenis aset dan model pengelolaan wakaf tradisional (Paksi, Manzilati, and Ekawaty 2018). Pemahaman masyarakat tentang wakaf masih terbatas dan hanya pada wakaf untuk peruntukan masjid, sekolah dan tanah pemakaman. Sedangkan instrumen wakaf kontemporer seperti wakaf saham kurang diketahui. Sehingga dibutuhkan strategi penghimpunan wakaf saham di pasar modal Indonsia. Penelitian mengenai wakaf dengan pendekatan SWOT (Strengh, Weakness, Opportunity, and Treat) pernah dilakukan oleh Permaisela (2019) dengan fokus pada manajemen wakaf produktif dan Ayuniyyah dkk (2019) mengenai manajemen wakaf yang dilakukan pada Badan Wakaf Indonesia. Sedangkan penelitian mengenai strategi penghimpunan wakaf saham dengan pendekatan SWOT belum pernah dilakukan.

Penelitian ini bertujuan untuk menganalisis strategi penghimpunan wakaf saham di Indonesia dengan pendekatan analisis faktor SWOT. Penggunaan metode Analytic Network Process (ANP) dalam penelitian ini berupaya untuk menentukan suatu pengambilan keputusan mengenai strategi penghimpunan wakaf saham yang paling tepat dengan mempertimbangkan faktor terpenting berdasarkan pendekatan kekuatan, kelemahan, peluang dan ancaman.

\section{KAJIAN PUSTAKA}

Wakaf Saham merupakan wakaf yang objek harta bendanya berupa saham syariah dan keuntungan investasi dari saham syariah yang tercatat di Bursa Efek Indonesia dan masuk ke dalam Indeks Saham Syariah Indonesia. Pihak-pihak yang terlibat dalam wakaf saham yaitu: wakif yaitu orang yang mewakafkan; nazhir atau orang yang dipercaya untuk mengelola wakaf yaitu perusahan sekuritas atau manajer investasi; dan manquf alaih sebagai penerima manfaat hasil wakaf (Abdulloh 2019). Mekanisme wakaf melalui instrumen saham, yaitu: pertama, wakaf uang yang diinvestasikan melalui saham, wakaf uang ini dapat dilakukan dengan menginvestasikan dananya melalui pembelian saham-saham perusahaan baik melalui pasar modal maupun tidak. Pada praktik wakaf ini, yang menjadi objek wakaf adalah uang, hanya bentuk investasinya dikelola melalui saham. Kedua, Wakaf Saham melalui uang, pada mekanisme ini wakaf dapat mewakilkan pada pihak nazhir atau pihak lainnya dengan menitipkan sejumlah uang yang kemudian dibelikan atau ditukar dengan saham, kemudian saham tersebut diwakafkan. Ketiga, wakaf uang yang disusun dalam skim saham sebagai penyertaan dalam wakaf, bentuk wakaf uang yang disusun dalam skim saham wakaf, wakif melalui wakaf uang dengan cara membeli unit-unit saham tersebut sesuai untuk tujuan wakaf seperti pembangunan rumah ibadah, pendidikan, pelayanan kesehatan, dan sebagainya untuk 
tujuan kepentingan dan kebajikan umat islam. Keempat, wakaf saham milik, Pada mekanisme wakaf saham ini, wakif memang sebelumnya merupakan pemegang saham suatu perusahaan, kemudian mewakafkan saham yang dimilikinya tersebut (M. E. Burhanudin 2017).

Wakaf saham diaplikasikan dengan dua model, yaitu (a) wakaf dari dividen saham dan (b) wakaf dari saham syariah sendiri. Wakaf dari dividen saham yaitu memotong dividen saham syariah dan disetorkan kepada lembaga wakaf dan diwujudkan dalam bentuk aset produktif atau aset sosial. Adapun wakaf saham langsung yaitu mewakafkan saham yang dibeli dan disetorkan pada pengelola investasi. Pengelola investasi ini yang mengelola saham yang diwakafkan tersebut dan keuntungannya baru diwujudkan menjadi aset produktif atau sosial. Adanya wakaf saham yang pengambilan wakafnya dari saham maupun dividen saham, maka semakin meningkatkan minat saham syariah, karena dengan membeli saham syariah, tidak hanya memperoleh keuntungan duniawi, namun dapat menjadi sarana ibadah karena dari saham dapat berwakaf. Dengan wakaf saham, investor dapat berinvestasi sekaligus berkegiatan sosial (Prasetyo 2019).

Maybank Islamic Berbad's Corporate Waqf yang diimplementasikan Johor Corporation Malaysia diakui secara global sebagai sebuah Tanggung Jawab Sosial Perusahaan yang Islami. Dividen yang diperoleh dari wakaf saham dimanfaatkan untuk masyarakat (Khairi et al. 2015; Khairil Faizal Khairi et al. 2014). Dana wakaf juga memegang peranan penting dalam pengembangan ekonomi komunitas Muslim di Penang, Malaysia. Waqf Fund Scheme berkontribusi dengan cara menghadirkan sebuah fasilitas keuangan terhadap akuisisi aset wakaf atau melalui dukungan uang tunai yang disalurkan kepada asosiasi atau komite sebuah masjid (Suhaimi, Rahman, and Marican 2014).

Model wakaf saham korporasi (corporate share waqf) menjadi salah satu alat yang populer karena sejalan dengan kebutuhan sektor korporasi untuk berpartisipasi dalam program yang berorientasi sosial. Hal ini dapat membantu korporasi untuk mencapai misi dan visi mereka dan secara tidak langsung berkontribusi pada pembangunan ekonomi dan kemasyarakatan. Model Wakaf Saham Korporasi juga mendapatkan sambutan yang sangat baik dan diakui dunia karena telah memenuhi persyaratan Tanggung Jawab Sosial Perusahaan (Thaker and Thaker 2015).

Selain wakaf saham, penghimpunan wakaf berkembang menjadi tiga inovasi model berikut: Venture Philanthropy of Waqf Model (VPWM), Value-Based Capital Model of Waqf (VBCM), dan Social Enterprise Waqf Fund Model (SEWF). Venture Philanthropy of Waqf Model merupakan pengelolaan penggalangan dana wakaf yang dapat menghasilkan sumber pendanaan baru guna mencapai imbal hasil finansial dan sosial atas investasi tertentu; Value-Based Capital Model of Waqf merupakan pengelolaan penggalangan dana wakaf yang dapat menghasilkan sumber pendanaan baru guna mencapai imbal hasil finansial dan sosial atas investasi tertentu, dan; Social Enterprise Waqf Fund Model merupakan praktik perbaikan dalam pengelolaan penggalangan dana wakaf yang dapat dilaksanakan oleh berbagai lembaga wakaf di banyak negara (Shulthoni et al. 2018).

Adapun beberapa faktor-faktor yang mempengaruhi penghimpunan wakaf uang/tunai atau wakaf saham yaitu: (i) Persepsi nazhir dipengaruhi oleh akses terhadap media informasi dan 
pemahaman atas aturan mengenai wakaf. Latar belakang pendidikan juga berpengaruh terhadap terbentuknya persepsi atau pemahaman nazhir (Dahlan 2014); (ii) Dukungan hukum yang menciptakan rasa aman bagi wakif/ orang yang berwakaf (Khairunisa, Akbar, and Devi 2017); Aspek pencatatan dengan akuntansi syariah yang digunakan secara tepat memb membuktikan relevansinya untuk redistribusi sukarela dan lembaga pengelolaan harta (Saidu 2019); (iii) Rasio penduduk Muslim, jumlah masjid dan jumlah ulama (Nurdany 2019); dan (iv) Lingkungan sosial, pemahaman dan promosi mengenai wakaf uang (Iqbal et al. 2019).

\section{Penelitian Terdahulu}

Penelitian dengan topik perwakafan dengan menggunakan pendekatan Analytic Network Process sudah banyak dilakukan. Seperti Penelitian Hasim yang menganalisis faktor-faktor yang memengaruhi penghimpunan wakaf uang di Indonesia yang terbagi menjadi tiga klaster, yaitu kelembagaan, masyarakat, dan pemerintahan. Klaster kelembagaan dipilih sebagai klaster yang paling berpengaruh terhadap tingkat penghimpunan wakaf uang. Klaster kelembagaan tersebut terdiri dari tiga sub-klaster yang paling berpengaruh yaitu kefokusan lembaga nazhir, pemahaman masyarakat terhadap wakaf uang, dan kelengkapan perangkat hukum yang berkenaan dengan wakaf uang (Hasim, Lubis, and Ali 2016).

Penelitian Fitri menganalisis permasalahan wakaf produktif dan solusinya di Kabupaten Banjarnegara dengan pendekatan Analytic Network Process dengan membagi tiga klaster masalah. Hasil penelitian menunjukkan bahwa prioritas utama klaster masalah sumber daya manusia adalah kemampuan manajerial nazhir yang masih rendah. Klaster masalah kelembagaan yang menjadi prioritas utama adalah peran BWI Kabupaten Banjarnegara belum optimal. Sedangkan prioritas klaster masalah pemerintah adalah kurangnya dukungan dan peran pemerintah. Adapun prioritas solusi dari masalah yang paling penting adalah pembinaan dan pendampingan nazhir (Fitri and Wilantoro 2018).

Hasil penelitian Khairunnisa dengan menggunakan Analytic Network Process mengungkapkan bahwa masalah penghimpunan wakaf uang dibagi menjadi dua kluster yaitu internal dan eksternal. Masalah internal yang paling menentukan adalah masalah yang terkait lembaga penghimpunan wakaf uang yaitu kurangnya standar manajemen wakaf, kurangnya pengetahuan nazhir, kurangnya ekposur produk, kurangnya sistem IT, kurangnya standar laporan keuangan, dan produk yang terbatas. Sedangkan masalah eksternal yang paling menentukan adalah yang berhubungann dengan komunitas dan pemerintah yaitu kurangnya eksposure aksi wakaf, kurangnya pengetahuan dan pemahaman masyarakat, ketidakadaan rancangan bangun wakaf uang, perbedaan mazhab fiqih, ketiadaan regulasi teknsi wakaf uang, dan kurangnya perlindungan hukum asset wakaf (Khairunnisa and Priantina 2019).

Adapun penelitian mengenai wakaf dengan pendekatan SWOT dan metode Analytic Network Process salah satunya adalah penelitian Ayuniyah yang mengevaluasi manajemen wakaf di Indonesia yang dilakukan oleh Badan Wakaf Indonesia. Berdasarkan kerangka analisis SWOT, penelitian menyimpulkan bahwa: kerjasama yang baik antar institusi wakaf sebagai prioritas kekuatan (Strength), kurangnya intergrasi antara Badan Wakaf Indonesia dengan lembaga wakaf lainnya sebagai prioritas kelemahan (Weakness), wakaf uang dan wakaf tanah yang potensial sebagai prioritas potensi (Opportunity), dan masalah nazhir sebagai prioritas 
ancaman (Threat). Strategi yang paling tepat yaitu kerjasama dan kolaborasi seluruh pemangku kepentingan wakaf (Ayuniyyah, Devi, and Kartika 2019).

Sebagai pembanding penelitian Ayuniyah, penelitian Permaisela hanya menggunakan pendekatan SWOT dalam manajemen wakaf produktif sebuah kebun sengon yang dikelola Dompet Dhuafa. Hasil penelitian menyatakan bahwa faktor kekuatan (Strenght) adalah tanahnya yang subur dan manajemen Dompet Dhuafa yang berpengalaman dalam pengelolaan wakaf produktif, Faktor kelemahan (Weakness) adalah jarak tanam yang terlalu dekat serta kurangnya penyemprotan hama yang ada di dalam pohon sengon. Faktor peluang (Opportunity) adalah terbukanya kerjasama dengan perusahaan/pedagang kayu, terbukanya peluang ekspor untuk meningkatkan devisa pemerintah dan harga pasar pohon sengon yang baik. Sedangkan faktor ancaman (Threat) yang dihadapi adalah adanya faktor alam seperti cuaca yang buruk hingga mengakibatkan pohon sengon tumbang (Permaisela 2019).

Penelitian menggunakan Analytic Network Process banyak diimplementasikan dalam berbagai analisis pengambilan keputusan selain bidang perwakafan seperti penelitian Apriadi dan Haura dalam bidang Baitul Maal wa Tamwil (Apriadi and Alexandi 2013; Haura, Baga, and Tanjung 2016), penelitian Aulia pada bidang Bank Pembiayaan Rakyat Syariah (Aulia, Hasanah, and Irfany 2020), penelitian Rusydiana pada bidang bank syariah (Rusydiana and Hasib 2019), hingga penelitian Fitriani pada bidang perzakatan (Fitriani and Priantina 2016). Penelitian ini berfokus pada topik wakaf saham dan strategi penghimpunannya dengan menggunakan pendekatan SWOT dan menggunakan metode Analytic Network Process. Wakaf saham merupakan salah satu wakaf produkti yang terdapat di pasar modal syariah yang relative berbeda dengan wakaf produktif lainnya. Penelitian wakaf saham sangat erat dengan bagaimana perkembangan saham syariah sebagai sebagai salah satu instrumen investasi syariah di pasar efek yang apabila wakaf saham berkembang, maka berdampak secara langsung pada pasar saham syariah. Penelitian ini mencoba menemukan temuan strategi yang tepat untuk penghimpunan wakaf saham yang masih belum optimal saat ini.

\section{METODE PENELITIAN}

Penelitian ini merupakan penelitian lapangan menggunakan pendekatan kualitatif dengan metode Analitic Network Process. Data yang digunakan merupakan data primer yang diperoleh melalui dari hasil wawancara mendalam (indepth interview) dan instrument kuisioner yang disebarkan pada sejumlah responden dengan teknik sampel non-probanity yaitu purposive sampling. Pemilihan responden dalam penelitian ini menimbang kepada kepakaran dan pengalaman dalam perwakafan secara umum dan wakaf saham secara khusus. Adapun rensponden penelitian dibagi menjadi 3 kategori berdasarkan kepakaran masing-masing yang berkaitan dengan perwakafan terutama wakaf saham. Responden penelitian ini adalah terdiri 9 (sembilan) orang yang terbagi menjadi 3 (tiga) kategori yaitu sekuritas, nazhir, dan regulator sebagai berikut: 
Tabel 1: Responden Penelitian

\begin{tabular}{lll}
\hline KATEGORI & LEMBAGA & PEKERJAAN \\
\hline \multirow{2}{*}{ Sekuritas } & Philips Sekuritas & Head of POEMS Syariah \\
\cline { 2 - 3 } & BNI Sekuritas & Head of e-Smart Syariah \\
\cline { 2 - 3 } & MNC Sekuritas & Head of MNC Trade Syariah \\
\hline \multirow{3}{*}{ Nazhir } & Dompet Dhuafa & General Manajer Pengembangan Wakaf \\
\cline { 2 - 3 } & Global Wakaf & Chief Executive Officer \\
\cline { 2 - 3 } & Rumah Wakaf & Chief Executive Officer \\
\hline \multirow{3}{*}{ Regulator } & Badan Wakaf Indonesia & Anggota Komisioner \\
\cline { 2 - 3 } & Otoritas Jasa Keuangan & Divisi Pasar Modal Syariah \\
\cline { 2 - 3 } & Bursa Efek Indonesia & Kepala Divisi Pasar Modal Syariah \\
& &
\end{tabular}

Analitic Network Process (ANP) adalah teori matematis yang memungkinkan pengambilan keputusan terhadap faktor-faktor yang saling berhubungan (dependence) serta umpan balik (feedback) secara sistematik. ANP juga satu dari metode pengambilan keputusan berdasarkan banyak kriteria yang dikembangkan oleh Thomas L. Saaty dan merupakan perkembangan kelanjutan dari metode terdahulu yaitu Analityc Hierarchy Process (AHP). ANP digunakan untuk memecahkan masalah yang bergantung pada alternatif-alternatif dan kriteria-kriteria yang ada. Adapun tahapan-tahapan penelitian dengan menggunakan teknik analisis ANP adalah sebagai berikut (Tanjung and Devi 2013):

Pertama, Dekomposisi Model. Tahap dekomposisi atau konstruksi model guna untuk mengidentifikasi, menganalisis, dan menstruktur kompleksitas masalah penelitian ke dalam jaringan ANP bantuan software Superdecision. Kontruksi model penelitian ini bersumber dari hasil wawancara mendalam dengan stakeholder wakaf saham yaitu sekuritas, nadzhir, Bursa Efek Indonesia dan Badan Wakaf Indonesia. Konstruksi model penelitian yang dihasilkan tersebut memahami masalah wakaf saham dan strategi penghimpunannya berdasarkan pendekatan klaster-klaster SWOT yaitu klaster kekuatan, klaster kelemahan, klaster peluang, dan klaster ancaman. Sedangkan klaster alternatif yaitu klaster strategi yang terdiri dari klaster strategi kekuatan-peluang, klaster kekuatan-ancaman, klaster kelemahan-peluang, dan klaster kelemahan-ancaman. Validasi model penelitian dilakukan dengan salah satu respoden penelitian ini.

Kedua, Kuantifikasi Model. Tahan kuantifikasi model terdiri dari: (i) mendesain kuisioner perbandingan pairwise dalam format jaringan ANP, (b) menguji kuisioner kuisioner kepada responden penelitian, (c) pengolahan data kuisioner dengan bantuan software SuperDecisions. 
Dalam proses analisisnya, metode ANP menggunakan skala pengukuran pairwise compariton atau perbandingan berpasangan sebagai desain kuisioner yang selanjutnya akan digunakan dalam survei terhadap responden. Adapun panduan skala pada pembuatan kusioner pairwise comparision adalah sebagai berikut:

Tabel 2. Skala Pengukuran dalam Analitic Network Process

\begin{tabular}{clll}
\hline $\begin{array}{c}\text { Tingkat } \\
\text { Kepentingan }\end{array}$ & Deskripsi & Penjelasan & \\
\hline 1 & $\begin{array}{l}\text { Sama besar pengaruh/ } \\
\text { tingkat kepentingannya }\end{array}$ & $\begin{array}{l}\text { Dua elemen yang dibandingkan memiliki } \\
\text { kontribusi kepentingan yang sama terhadap } \\
\text { tujuan. }\end{array}$ \\
\hline 2 & $\begin{array}{l}\text { Sedikit lebih besar } \\
\text { pengaruhnya/ } \\
\text { kepentingannya }\end{array}$ & $\begin{array}{l}\text { Pengalaman dan penilaian sedikit } \\
\text { mendukung satu elemen diandingkan elemen } \\
\text { yang lain. }\end{array}$ \\
\hline 3 & $\begin{array}{l}\text { Lebih besar pengaruhnya/ } \\
\text { tingkat kepentingannya. }\end{array}$ & $\begin{array}{l}\text { Pengalaman dan penilaian kuat mendukung } \\
\text { satu elemen dibandingkan elemen lainnya. }\end{array}$ \\
\hline 5 & $\begin{array}{l}\text { Sangat lebih besar } \\
\text { pengaruh/ } \\
\text { kepentingannya. }\end{array}$ & $\begin{array}{l}\text { Satu elemen sangat lebih dibandingkan } \\
\text { elemen lainnya, dan dominan ditunjukan } \\
\text { dalam praktik. }\end{array}$ \\
\hline 7 & $\begin{array}{l}\text { Amat sangat lebih besar } \\
\text { pengaruhnya/ } \\
\text { kepentingannya. }\end{array}$ & $\begin{array}{l}\text { Bukti-bukti yang memihak satu elemen } \\
\text { lainnya memiliki bukti yang tingkat } \\
\text { kemungkinan afirmasinya tertinggi. }\end{array}$ \\
\hline 9 & &
\end{tabular}

Sumber: dimodifikasi Saaty (2006) dalam (Tanjung and Devi 2013)

Ketiga, Intrepretasi Hasil dan Sintesis. Hasil analisis diekspor kedalam software Microsof Excel untuk menghasilkan luaran sebagaimana tujuan penelitian. Rata-rata geometrik dari semua tanggapan responden yang dibagi kedalam tiga kategori dihitung dan disintesis untuk menghasilkan koefisien tingkat kesepakatan keseluruhan responden. Interpretasi hasil dengan rata-rata geometrik digunakan untuk merumuskan kesimpulan penelitian ini. Alat analisis yang digunakan ANP sebagai berikut:

(i) Konsistensi. Analisis yang digunakan untuk menentukan prioritas dalam analisas jaringan ANP adalah melalui perbandingan pasangan antara satu kriteria dengan kriteria lainnya.baik dalam klaster maupun sub-klasternya masing-masing. Tingkat inkonsistensi preferensi atau pengaruh pembandingan pasangan disarankan tidak lebih dari 10 persen. Artinya, jika perbandingan pasangan memiliki tingkat inkonsistensi lebih dari 0.1 atau 10 persen maka pembandingan pasangan yang dilakukan tidak konsisten dan akan berpengaruh terhadap hasil prioritas yang kurang dapat dipercaya. Inkosistensi dari matrik pendugaan dapat dihitung 
sebagai fungsi dari nilai maksimum eigenvalue $\left(\lambda_{\max }\right)$ dan jumlah $\mathrm{n}$ dalam matriks sebagai berikut:

$$
\mu \equiv \frac{\lambda_{\max }-n}{n-1}(1)
$$

Keterangan:

$\mu=$ consistency index;

$\lambda_{\max }=$ maximum eigenvalue of matrix $A$;

$n=$ order of matrix $A$.

(ii) Group Judgment; Untuk mengetahui hasil penilaian individu dari para responden dan menentukan hasil pendapat pada satu kelompok dilakukan penilaian dengan menghitung geometric mean/ rata-rata geometrik. Pertanyaan berupa perbandingan (Pairwise comparison) dari responden akan dikombinasikan sehingga membentuk suatu konsensus. Geometric mean merupakan jenis penghitungan rata-rata yang menunjukan tendensi atau nilai tertentu dimana memiliki formula sebagai berikut:

$$
G M_{k}=\sqrt[n]{\left(R_{1} * R_{1} * \cdots * R_{n}\right)}
$$

\section{Keterangan}

$\mathrm{GM}=$ Geometric Mean;

$R=$ judgment of individual respondent;

$n=$ number of respondents;

$k=$ number of pairwise comparisons.

(iii) Rater of Agreement. Rater of agreement merupakan ukuran yang menunjukan tingkat kesesuaian/ persetujuan para responden penelitian (R1-Rn) terhadap suatu masalah dalam satu klaster. Adapun alat yang digunakan untuk mengukur rater agreement adalah rumus Kendall's Coefficient of Concordance $(\mathrm{W} ; 0<\mathrm{W} \leq 1)$. Dimana apabila nilai $\mathrm{W}=1$ menunjukan kesesuaian yang sempurna. Adapun rumus Kendall's (W) adalah sebagai berikut:

$$
W=\frac{12 S}{m^{2}\left(n^{3}-n\right)}
$$

\section{Keterangan:}

$$
\begin{aligned}
& \mathrm{w}=\text { Kendall's coefficient } \\
& \mathrm{n}=\text { Total object } \\
& \mathrm{m}=\text { Total judges } \\
& \mathrm{s}=\text { the sum of quadratic deviation } .
\end{aligned}
$$


Jika nilai pengujian $\mathrm{W}$ sebesar $1(\mathrm{~W}=1)$, dapat disimpulkan bahwa penilaian atau pendapat dari para responden memiliki kesesuaian yang sempurna. Sedangkan ketika nilai W sebesar 0 atau semakin mendekati 0 , maka menunjukan adanya ketidaksesuaian antar jawaban responden atau jawaban bervariatif.

\section{HASIL PENELITIAN DAN PEMBAHASAN}

\section{Kontruksi Model Penelitian}

Dekomposisi model penelitian ini bersumber dari hasil wawancara mendalam praktisi wakaf saham di Bursa Efek Indonesia. Berdasarkan hasil wawancara, dekomposisi faktor-faktor SWOT yang berpengaruh pada penghimpunan wakaf saham di Indonesia adalah sebagai berikut: (a) Faktor Kekuatan meliputi: (i) Adanya fatwa MUI dan undang-undang, dan (ii) Kolaborasi antara regulator, lembaga sekuritas dan lembaga nazhir; (b) Faktor Kelemahan meliputi: (i) Risiko penurunan nilai saham, dan (ii) Pemahanan nazhir mengenai wakaf saham yang masih sedikit; (c) Faktor Peluang meliputi: (i) Market share pasar modal mempunyai ruang tumbuh lebih besar, dan (ii) Minat masyarakat untuk berinvestasi saham syariah; dan (d) Faktor Ancaman meliputi: (i) Mindset tradisional masyarakat tentang wakaf, dan (ii) Kurangnya realisasi masyarakat untuk berwakaf saham.

Sedangkan stategi-strategi alternatif dalam penghimpunan wakaf saham di Indonesia adalah sebagai berikut: (a) Strategi Kekuatan-Peluang (SO) yaitu meliputi: (i) Mengoptimalkan kerjasama antara lembaga nazhir dan lembaga sekuritas sebagai mitra kerja, dan (ii) Mengeluarkan aturan teknis wakaf saham; (b) Strategi Kekuatan-Ancaman (ST) yaitu meliputi: (i) Kampanye media sosial, dan (ii) Seminar/Webinar disertai pembukaan rekening saham; (c) Strategi Kelemahan-Peluang (WO) yaitu meliputi: (i) Pembekalan pemahaman lembaga nazhir, dan (ii) Kerjasama Antar Sekuritas/Manajer Investasi; dan (d) Strategi KelemahanAncaman (WT') yaitu meliputi: Peningkatan pelayanan kelembagaan, Menanamkan kepercayaan masyarakat.

Dekomposisi konstruks model penelitian mengenai strategi penghimpunan wakaf saham dengan pendekatan analisis SWOT di Indonesia sebagai mana digambarkan pada Gambar 1 berikut: 


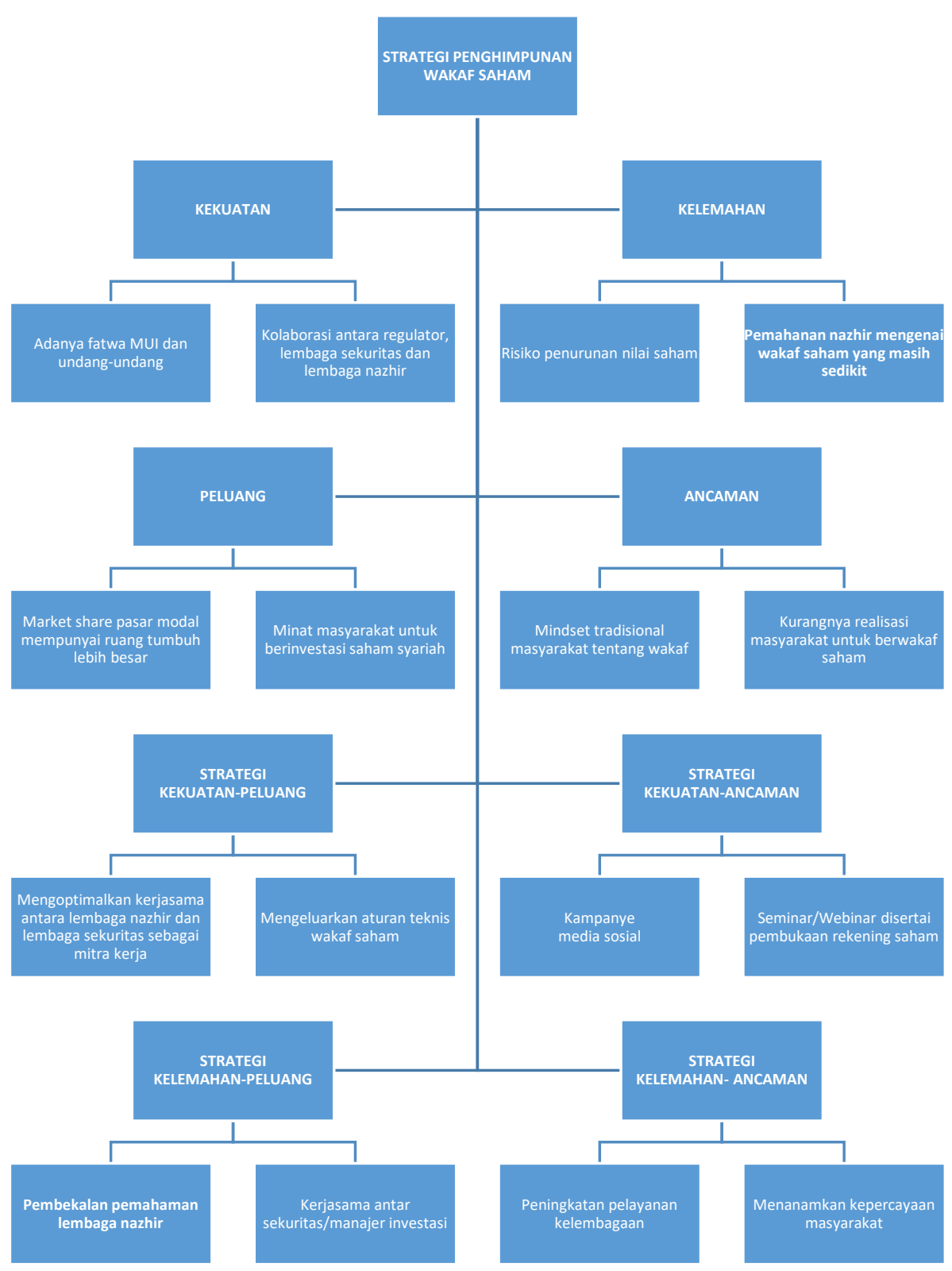

Sumber: Penelitian (2020)

Gambar 1. Konstruksi Model Penelitian

Adapun dekomposisi konstruk model penelitian dengan menggunakan bantuan software superdecision adalah sebagai berikut: 


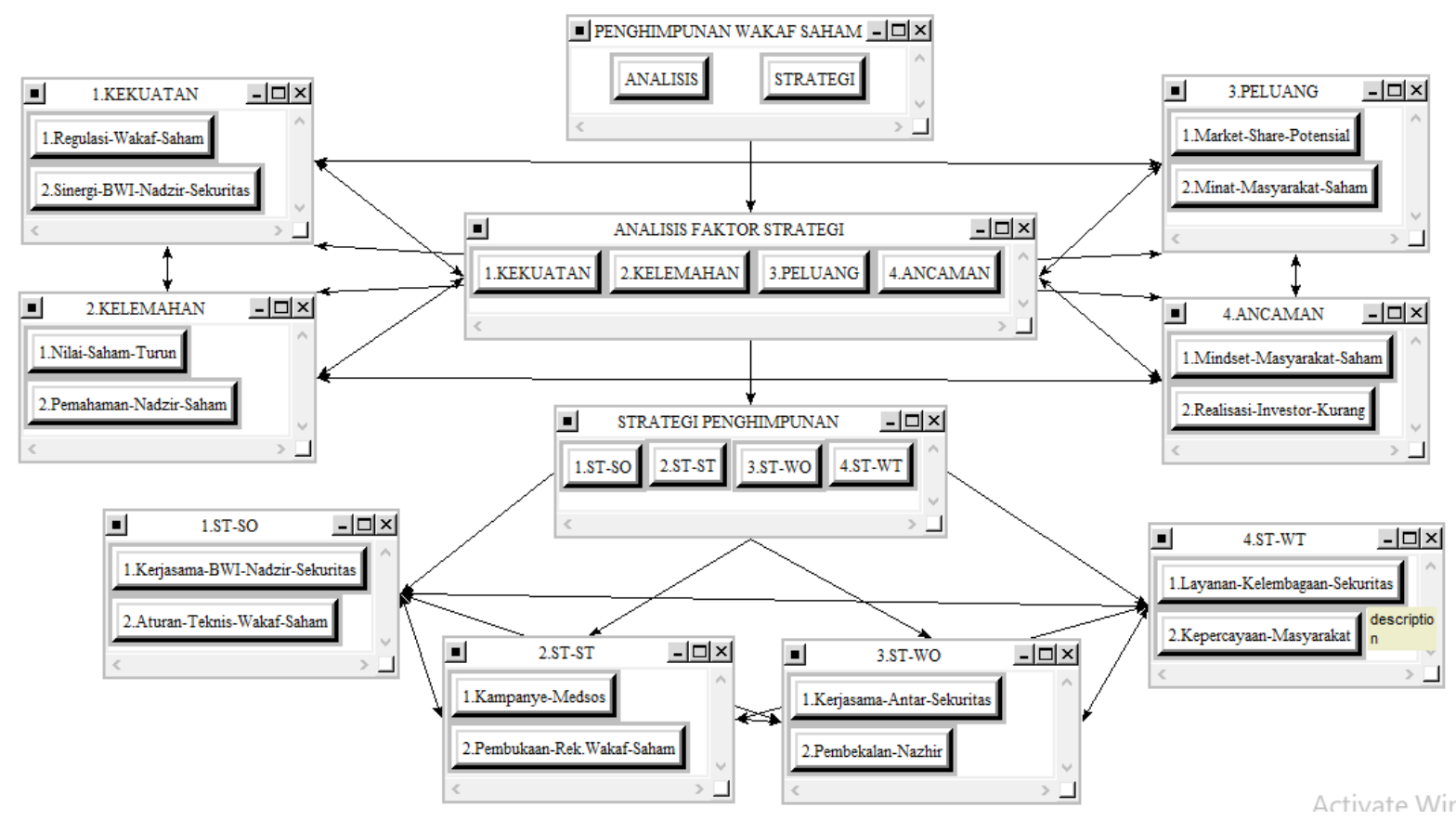

Sumber: Penelitian (2020)

Gambar 2. Konstruksi Jaringan ANP

\section{Analisis Faktor Kekuatan (Strength)}

Klaster kekuatan dipengaruhi oleh aspek Kolaborasi antara regulator, lembaga sekuritas dan lembaga nazhir dengan nilai prioritas mencapai 0,606 dan aspek regulasi hanya 0,357. Hal tersebut menunjukan bahwa rata-rata seluruh responden baik akademisi, praktisi dan regulator memutuskan bahwa aspek sinergitas merupakan faktor kekuatan dalam penghimpunan wakaf saham di Indonesia. Adapun hasil analisis faktor kekuatan penghimpunan wakaf saham adalah sebagai berikut:

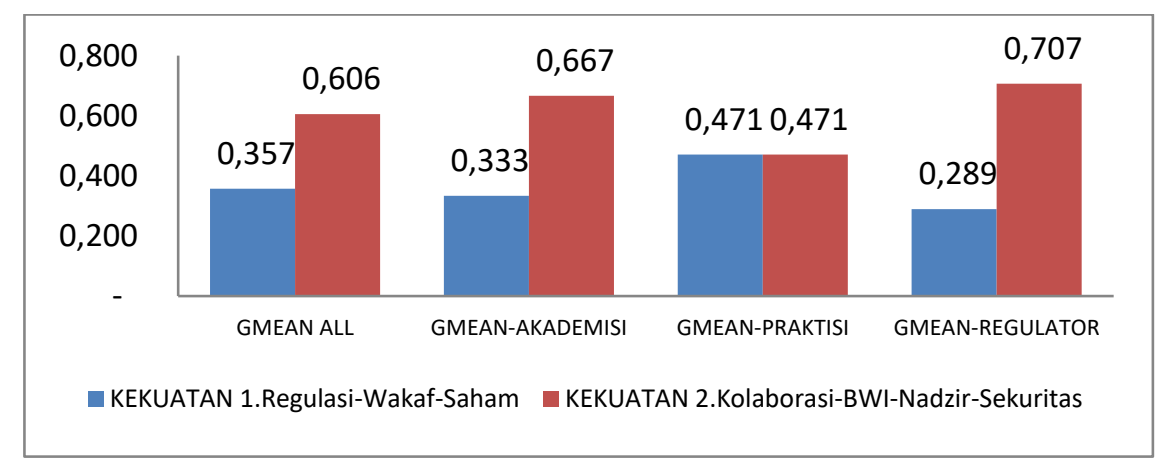

Sumber: Penelitian (2020)

Gambar 3. Rata-rata Geometrik Faktor Kekuatan 


\section{Analisis Faktor Kelemahan (Weakness)}

Analisis faktor kelemahan seluruh responden penelitian baik akademisi, praktisi dan regulator memprioritaskan aspek pemahaman nazhir mengenai wakaf saham dengan rata-rata geometrik 0,656 dibandingkan aspek nilai saham yang turun hanya 0,287. Hal tersebut menujukan pemahaman nazhir wakaf saham yang masih rendah merupakan faktor kelemahan dalam penghimpunan wakaf saham di Indonesia saat ini. Adapun hasil analisis faktor kelemahan penghimpunan wakaf saham adalah sebagai berikut:

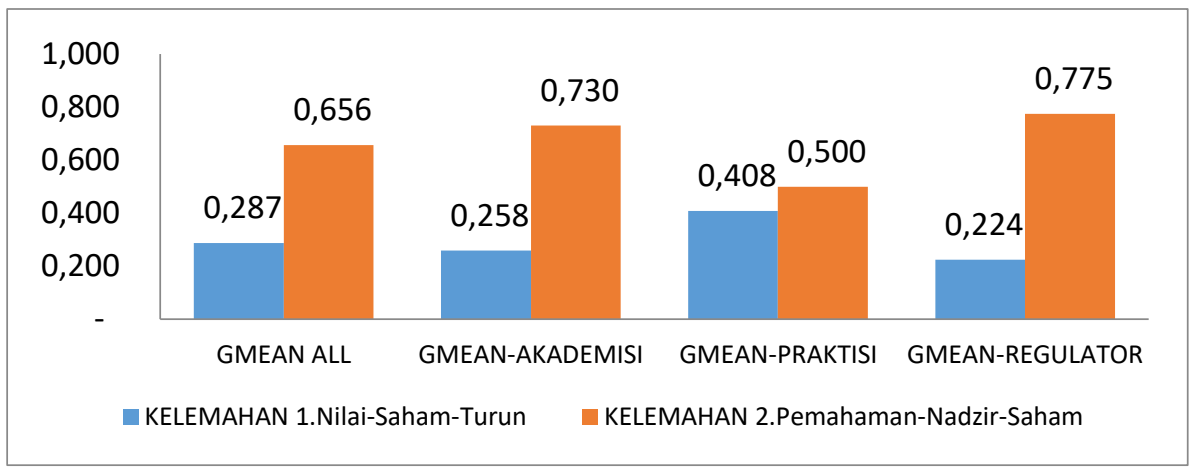

Sumber: Penelitian (2020)

Gambar 4. Rata-rata Geometrik Faktor Kelemahan

\section{Analisis Faktor Peluang (Opportunity)}

Aspek yang paling dari faktor peluang diprioritaskan rata-rata keseluruhan responden yaitu akademi dan regulator adalah market share wakaf saham yang potensial dengan rata-rata geometik mencapai 0,619 , sedangkan aspke minat masyarakat terhadap wakaf saham hanya 0,303. Praktisi memandang faktor peluang penghimpunan wakaf baik dari aspek market share pasar wakaf saham dan minat masyarakat berinvestasi dengan rata-rata yang sama yaitu 0,433. Secara umum dapat dindikasikan bahwa penghimpunan wakaf saham di Indonesia memiliki potensi market share yang cukup besar di masa yang akan datang. Adapun hasil analisis faktor peluang penghimpunan wakaf saham adalah sebagai berikut:

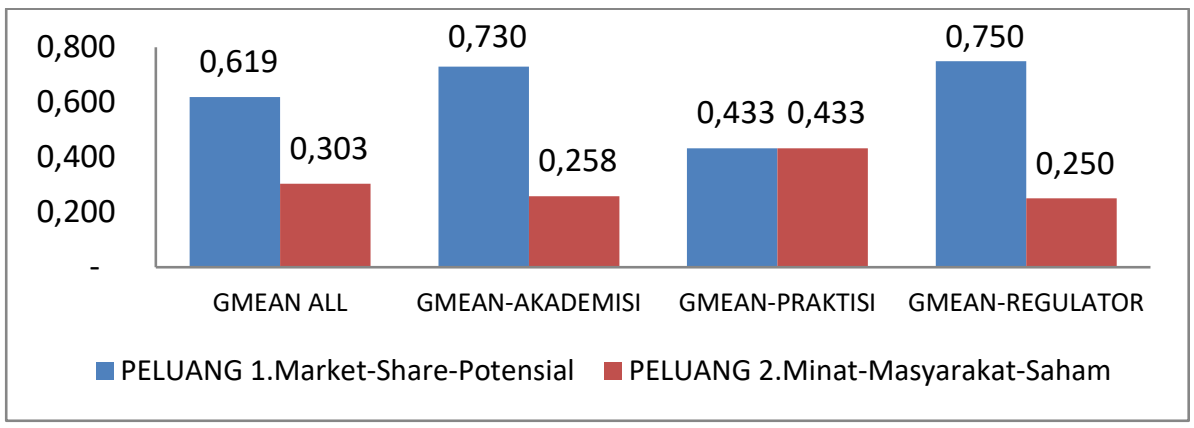

Sumber: Penelitian (2020)

Gambar 5. Rata-rata Geometrik Faktor Peluang 


\section{Analisis Faktor Ancaman (Threat)}

Aspek dari faktor ancaman yang paling diprioritaskan oleh rata-rata respoden baik akademisi, praktisi dan regulator adalah aspek mindset masyarakat terhadap wakaf saham itu sendiri dengan rata-rata geometrik mencapai 0,500 sedangkan aspek realisasi masyarakt untuk membeli wakaf saham hanya 0,408 . Sehingga dapat disimpulkan bahwa mindset yang tidak tepat mengenai wakaf saham saat ini menjadi ancaman bagi penghimpunan wakaf saham di Indonesia di masa yang akan datang. Adapun hasil analisis faktor ancaman penghimpunan wakaf saham adalah sebagai berikut:

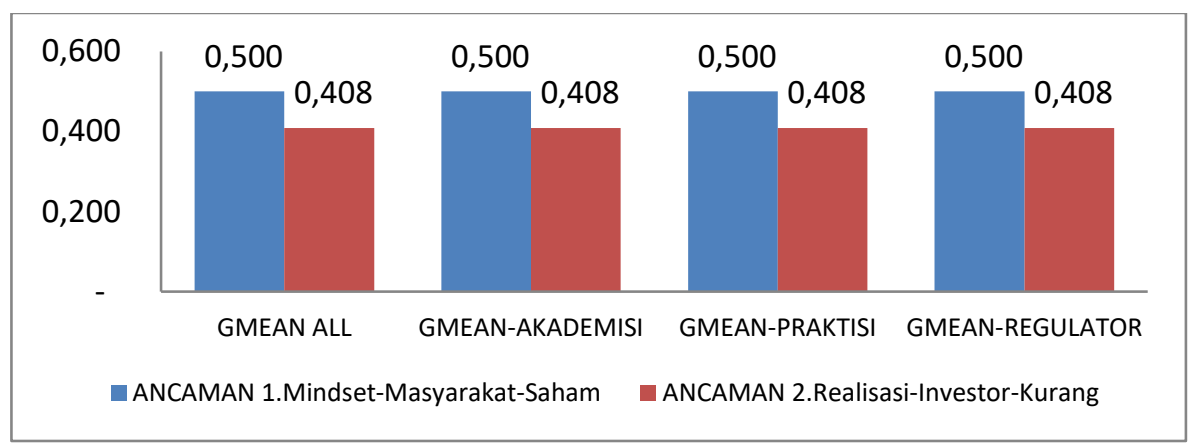

Sumber: Penelitian (2020)

Gambar 6. Rata-rata Geometrik Faktor Ancaman

\section{Analisis Faktor SWOT yang Paling Berpengaruh terhadap Penghimpunan Wakaf Saham}

Keseluruhan rekapitulasi faktor SWOT menunjukan bahwa faktor yang paling berpengaruh terhadap penghimpunan wakaf saham adalah faktor peluang. Seluruh responden memilih faktor peluang dengan rata-rata geometrik yaitu 0,343 . Sedangkan rata-rata geometrik faktor lainnya berurutan yaitu faktor kekuatan yaitu 0,265, faktor kelemahan yaitu 0,207, dan faktor ancaman yaitu 0,146 . Faktor peluang juga diprioritaskan berdasarkan nilai rata-rata geometrik setiap kategori responden baik responden akademisi yaitu 0,312, praktis yaitu 0,347, dan regulator yaitu 0,373 . Keseluruhan responden memilih faktor peluang sebagai faktor yang paling berpengaruh pada penghimpunan wakaf saham. Sehingga penghimpunan wakaf saham di Indonesia saat ini sangat dipengaruhi faktor peluang wakaf saham. Adapun gambaran ratarata geometrik keseluruhan kategori respoden pada seluruh faktor SWOT sebagai berikut:

\begin{tabular}{|c|c|c|c|c|c|c|}
\hline 0,400 & 0,343 & & \multirow{2}{*}{0,292} & 0,347 & \multicolumn{2}{|c|}{0,358} \\
\hline 0,300 & 0,265 & $0,249,267$ & & & 0,282 & \\
\hline 0,200 & $0,14 €$ & 0,160 & & 0,155 & 0,167 & 0,170 \\
\hline 0,100 & & & & & & \\
\hline & GMEAN ALL & GMEAN-AKADEMISI & GME & PRAKTISI & GMEAN-REC & LATOR \\
\hline & - KEKUATAN & KELEMAHAN & PELUANG & ANCAM & & \\
\hline
\end{tabular}


Sumber: Penelitian (2020)

\section{Gambar 7. Rata-Rata Geometrik Klaster Faktor SWOT}

\section{Analisis Strategi SWOT dalam Penghimpunan Wakaf Saham}

Berdasarkan masing-masing kategori responden, rata-rata geometrik responden praktisi dan regulator yang memprioritaskan strategi kelemahan-peluang (WO) sebagai strategi SWOT prioritas yaitu sebesar 0,266 dan 0,301. Sedangkan rata-rata geometik responden akademisi memprioritaskan strategi kekuatan-peluang (SO) sebagai strategi SWOT prioritas yaitu 0,284. Berdasarkan hasil analisis, strategi SWOT dalam penghimpunan wakaf saham di Indonesia yang menjadi prioritas seluruh responden adalah strategi peluang kelemahan-peluang (WO). Hasil menunjukan bahwa rata-rata geometrik keseluruhan responden yaitu 0,278 pada strategi kelemahan-peluang (WO) dan diikuti secara berurutan dengan strategi kekuatan-peluang (SO) yaitu 0,264, strategi kelemahan-ancaman (WT) yaitu 0,228 dan strategi kekuatan-tantangan (ST) yaitu 0,224. Hal tersebut menunjukan bahwa secara rata-rata geometrik keseluruhan responden memilih strategi kelemahan-peluang sebagai prioritas strategi penghimpunan wakaf saham di Indonesia saat ini. Adapun gambaran rata-rata geometrik keseluruhan kategori respoden pada seluruh strategi SWOT sebagai berikut:

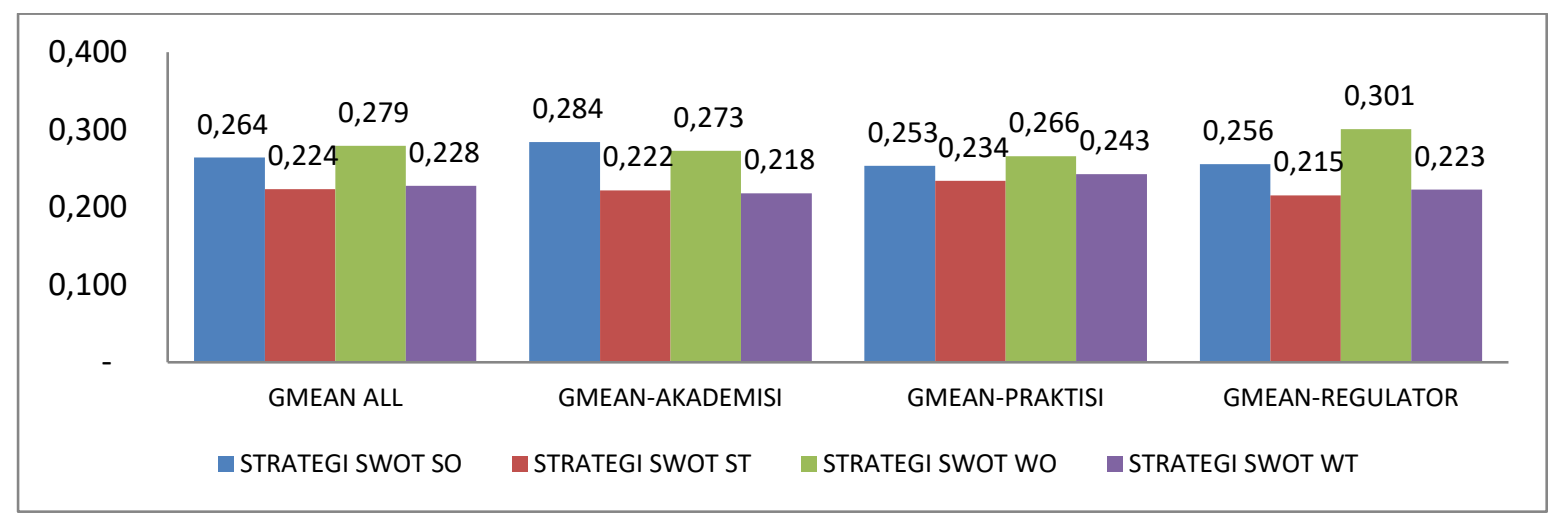

Sumber: Penelitian (2020)

Gambar 8. Rata-Rata Geometrik Strategi SWOT

\section{Analisis Strategi yang Paling Tepat dalam Penghimpunan Wakaf Saham di Indonesia}

Hasil analisis strategi penghimpanan wakaf berdasarkan kategori akademisi adalah strategi kolaborasi antara regulator, lembaga sekuritas dan lembaga nazhir pada strategi SWOT yaitu strategi kekuatan-peluang (SO) dengan rata-rata geometrik paling tinggi yaitu 0,622. Kategori praktisi memprioritaskan strategi pembekalan pemahaman lembaga nazhir yang termasuk dalam strategi kelemahan-peluang (WO) dengan rata-rata geometrik paling tinggi yaitu 0,634. Sedangkan kategori regulator memprioritaskan strategi kolaborasi antara regulator, lembaga sekuritas dan lembaga nazhir pada strategi SWOT yaitu strategi kekuatan-peluang (SO) dengan rata-rata geometrik paling tinggi yaitu 0,605. Adapun gambaran rata-rata geometrik keseluruhan kategori respoden pada seluruh strategi SWOT sebagai berikut: 


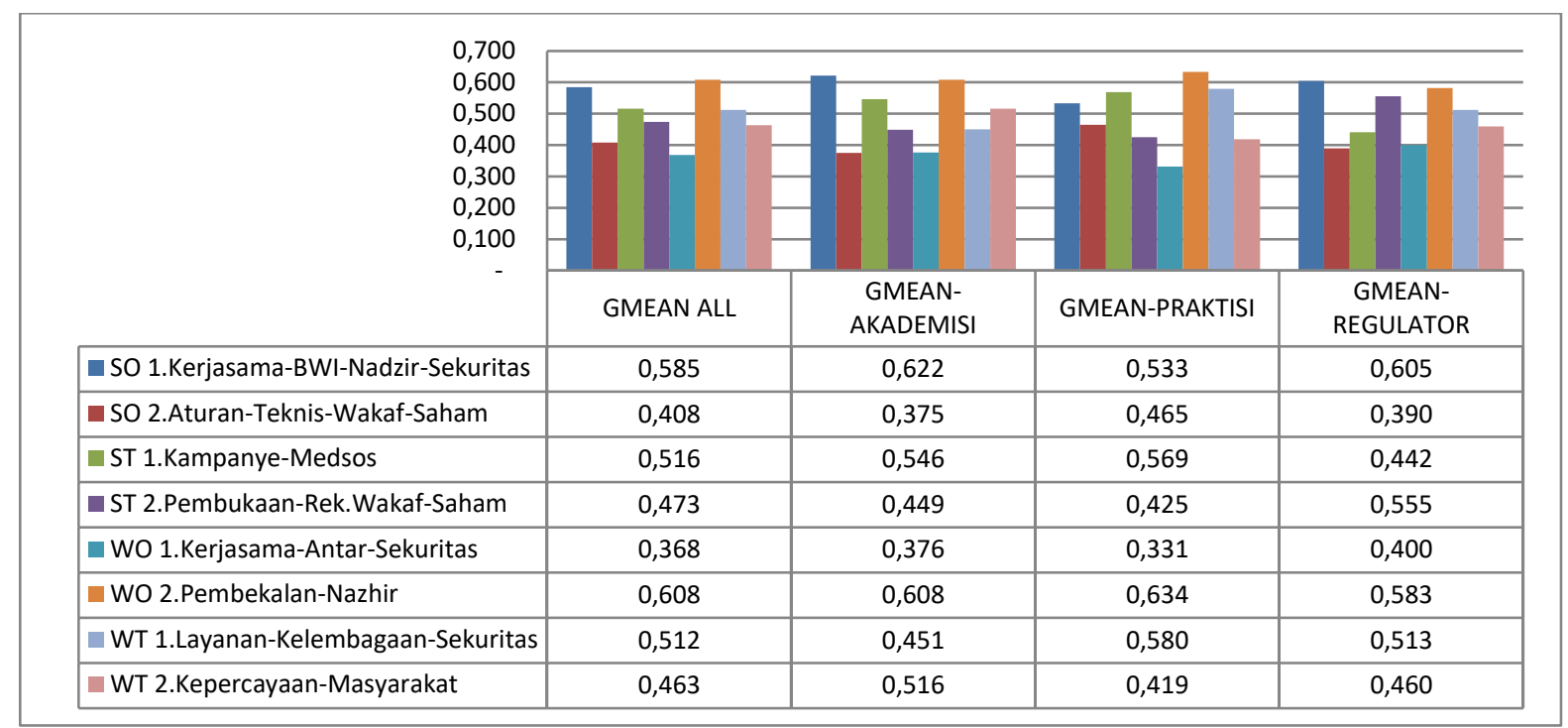

Sumber: Penelitian (2020)

Gambar 9. Rata-Rata Geometrik Keseluruhan Strategi

Hasil analisis berdasarkan keseluruhan respoden strategi SWOT menunjukan bahwa seluruh responden pada strategi pembekalan pemahaman lembaga nazhir yang termasuk dalam strategi kelemahan-peluang (WO) dengan rata-rata geometrik paling tinggi yaitu 0,608. Hal tersebut dapat disimpulkan bahwan strategi pembekalan pemahaman lembaga nazhir merupakan strategi yang paling tepat dalam penghimpunan wakaf saham di Indonesia saat ini.

\section{Analisis Tingkat Kesepakatan Responden}

Tingkat kesepakatan responden dalam setiap klaster dihitung menggunakan nilai koefisien Kendall (W) Jika nilai pengujian W sebesar $1(\mathrm{~W}=1)$, dapat disimpulkan bahwa penilaian atau pendapat dari para responden memiliki kesepakatan yang sempurna. Sedangkan ketika nilai W sebesar 0 atau semakin mendekati 0 , maka menunjukan adanya ketidaksepakatan antar jawaban responden atau jawaban bervariatif. Hasil analisis kesepakatan responden sebagaimana Tabel 3.

Tabel.3. Tingkat Kesepakatan Responden

\begin{tabular}{l|l|l}
\hline Klaster & W & Keterangan \\
\hline Faktor SWOT & 0.567 & Cukup Sempurna \\
\hline Strategi Penghimpunan Wakaf Saham & 0.135 & Kurang sempurna \\
\hline
\end{tabular}

Sub-Klaster Faktor SWOT

\begin{tabular}{l|l|l}
\hline Kekuatan & 0.44 & Cukup Sempurna \\
\hline Kelemahan & 0.44 & Cukup Sempurna \\
\hline
\end{tabular}




\begin{tabular}{l|l|l}
\hline Klaster & W & Keterangan \\
\hline Peluang & 0.44 & Cukup Sempurna \\
\hline Ancaman & 0 & Tidak Sempurna \\
\hline
\end{tabular}

Sub-Klaster Strategi Penghimpunan

\begin{tabular}{l|l|l}
\hline Strategi Kekuatan-Peluang (SO) & 1 & Sempurna \\
\hline Strategi Kekuatan-Ancaman (ST) & 0.11 & Kurang sempurna \\
\hline Strategi Kelemahan-Peluang (WO) & 0.44 & Cukup Sempurna \\
\hline Strategi Kelemahan-Ancaman (WT) & 0.11 & Kurang sempurna \\
\hline
\end{tabular}

Sumber: Penelitian (2020)

Koefisien Kendall pada klaster Faktor SWOT menunjukan tingkat kesepakatan yang responden yang cukup sempurna mencapai 0,567 . Hal tersebut menunjukan bahwa pendapat dari keseluruhan responden mengenai faktor SWOT yang diprioritaskan yaitu faktor peluang yang menjadi faktor penting dalam penghimpunan wakaf saham cukup disepakati oleh setiap respoden. Akan tetapi, koefisien Kendal pada klaster Strategi Penghimpunan menunjukan nilai kurang sempurna yaitu 0,135 . Hal tersebut menunjukan setiap responden memiliki pendapat yang bervariasi mengenai strategi SWOT yang diprioritaskan dalam penghimpunan wakaf saham.

Hal yang sama ditunjukan pada tingkat kesepatakan masing-masing responden pada Subklaster Faktor SWOT yaitu sebagian besar sub-klaster yaitu faktor kekuatan, faktor kelemahan, dan faktor peluang menujukan nilai cukup sempurna dengan nilai koefisien Kendall mencapai 0,44. Sedangkan sub-klaster faktor ancaman menunjukan hasil kesepatakan yang tidak sempurna. Hal tersebut menujukan bahwa dari prioritas faktor SWOT setiap kategori responden bervariasi. Koefisien Kendall sub-klaster Strategi Penghimpunan Wakaf Saham memiliki pendapat masing-masing responden yang beragam. Sub-klaster yang kurang sempurna terdapat pada strategi Kekuatan-Ancaman (ST) dan Kelemahan-Ancaman (WT) dengan koefisien Kendall mencapai 0,11. Dan koefisien Kendal sub-klaster strategi Kelemahan-Peluang (WO) cukup sempurna mencapai 0,44. Sedangkan hanya sub-klaster Strategi Kekuatan-Peluang (SO) yang memiliki nilai sempurna dengan koefisien Kendall sama dengan 1. Hal tersebut menunjukan bahwa seluruh responden memiliki kesepatakan yang sama/bulat terhadap prioritas strategi pada sub-klaster Strategi Kekuatan-Peluang (SO).

Mayoritas penduduk Muslim di Indonesia menjadi salah satu faktor yang menjadi potensi market share pasar modal terus tumbuh dengan positif. Bursa Efek Indonesia melaporkan bahwa per Desember 2019, jumlah investor saham syariah meningkat 54 persen dari sebelumnya 44.536 investor di akhir 2018 menjadi 68.599 investor. Jumlah tersebut mewakili 6,2 persen dari jumlah investor ritel Bursa Eefek Indonesia. Sedangkan menurut laporan Otoritas jasa keuangan menyatakan bahwa pasar modal syariah berkontribusi paling besar 
pada aset industri keuangan syariah sebesar 56,2 persen. Dari sisi market share, kapitalisasi pasar Indeks Saham Syariah Indonesia pada akhir tahun 2019 sebesar 51,55 persen, jika di bandingkan kapitalisasi Indek Harga Sahan Gabungan. Investor Pasar Modal Syariah di Bursa Efek Indonesia menunjukkan peningkatan jumlah per Juni 2020 mencapai 75.570 dari 68.599 investor pada akhir 2019 dengan pangsa 6,1 persen. Dengan meningkatnya penawaran saham syariah, maka peluang investor untuk berwakaf melalui saham syariahpun secara berkaitan akan meningkat. Market share wakaf saham yang potensial berkorelasi dengan pengembangan pasar saham syariah di Indonesia. Hal tersebut mengindikasikan bahwa sebuah peluang dalam penghimpunan wakaf saham di Indonesia.

Dalam pengelolaan dan pengembangan harta benda wakaf, nazhir memiliki yang peran yang fundamental. Nazhir dituntut memiliki integritas dan profesionalitas dalam mengelola dan mengembangkan harta benda wakaf khususnya wakaf saham. Selain pengetahuan positif mengenai regulasi perwakafan dan saham syariah, nadzir harus memiliki keterampilan mengelola investasi syariah pada pasar modal syariah. Hal tersebut salah satunya untuk memitigasi risiko kerugian akibat harga saham yang fluktuatif. Mitigasi risiko tersebut diupayakan untuk memaksimalkan keuntungan yang didapat yang berdampak secara langsung pada optimalnya manfaat wakaf dari saham syariah yang dikelo nadzir. Selain risiko harga saham yang fluktuatif, risiko dalam saham syariah juga dikenal dengan risiko investasi syariah dimana risiko tersebut disebabkan oleh keluarnya saham syariah yang dikelola oleh nazhir dari Daftar Efek Syariah (DES) yang diterbitkan oleh Otoritas Jasa Keuangan karena saham tersebut tidak memenuhi ketentuan syariah. Penjualan saham yang keluar dari DES tersebut akan berpotensi menghasilkan kerugian investasi apabila ternyata pada saat harga saham tersebut turun.

Nazhir sebagai pengelola investasi syariah dapat memitigasi potensi risiko yang melekat pada saham syariah dengan berinvestasi sesua dengan prinsip syariah. Pentingnya memahami perusahaan ataupun saham syariah yang ditransaksikan ada terhindar dari transaksi gharar/ketidakpastian adalah mengurangi risiko investasi syariah. Sedangkan untuk mengurangi risiko fluktuasi harga saham salah satunya yaitu dengan menggunakan analisis fundamental yang waib dalam melakukan analisis kinerja saham syariah seperti Return Of Equty (ROE), Earning Per Share (EPS), hingga Prive to Earning Ratio (PER) (Abdulloh 2019).

Strategi yang tepat dalam penghimpunan wakaf saham di Indonesia saat ini adalah strategi yang mengungguli faktor kelemahan penghimpunan wakaf dalam mengoptimalkan peluang penghimpunan wakaf saham itu sendiri. Faktor kelemahan penghimpunan yang disepakati adalah pemahaman nazhir wakaf saham yang belum memadai saat ini sedangkan faktor peluang penghimpunan wakaf saham yaitu pangsa pasar wakaf saham yang potensial. Sebagaimana potensi wakaf saham yang berkorelasi dengan potensi investasi pada saham syariah itu sendiri, sehingga pembekalan untuk nazhir penghimpun wakaf saham yaitu pengetahuan dan keterampilan berinvestasi saham syariah terutama dalam memitigasi risiko fluktuasi harga saham syariah dan risiko investasi syariah. Peningkatan pengetahuan dan keterampilan nazhir dalam mengelola investasi syariah dapat bekerja sama dengan prusahaan sekuritas dimana ia membuka rekening wakaf saham dan dalam pembuatan Akad Ikrar Wakaf Saham (AIWS) dengan wakif. Kerjasama dengan perusahaan sekuritas tersebut juga 
diharapkan saling memberikan manfaat terutama dalam menggarap pangsa pasar wakaf saham yang masih potensial.

Wakaf khususnya wakaf saham apabila dikelola secara profesional akan menjadi lembaga Islam potensial yang berguna dalam menyokong serta memperkokoh perekonomian umat. Hal tersebut dikarenakan maju mundurnya wakaf sangat ditentukan oleh kualitas manajemen pengelolaan wakaf. Pemahaman nazhir mengenai wakaf saham dapat dipengaruhi juga oleh akses terhadap media informasi dan pemahaman atas aturan mengenai wakaf juga latar belakang pendidikan (Dahlan 2014). Selain itu, apabila nazhir memiliki kefokusan pada pengelolaan harta wakaf seperti saham syariah dapat berpengaruh pada penghimpunan wakaf saham sendiri (Hasim, Lubis, and Ali 2016). Penelitian ini juga menyimpulkan nazhir sebagai masalah sumber daya dalam penghimpunan wakaf dengan solusi yang linear yaitu dengan peningkatan pengetahuan, pembinaan dan pendampingan nazhir (Fitri and Wilantoro 2018; Khairunnisa and Priantina 2019). Sedangkan berdasarkan manajemen wakaf yang dilakukan oleh Badan Wakaf Indonesia, nazhir sebagai masalah prioritas ancaman (Threat) (Ayuniyyah, Devi, and Kartika 2019).

Selain strategi kelemahan-peluang tersebut, penghimpunan wakaf saham juga harus didukung dengan sinergi dan kolaborasi antara Badan Wakaf Indonesia, perusahaan sekuritas dan nazhir sebagai investor syariah dalam mendorong informasi wakaf saham yang benar kepada masyarakat luas. Fatwa Dewan Syariah Nasional- Majelis Ulama Indonesia Nomor 80 Tahun 2011 mengenai Penerapan Prinsip Syariah dalam Mekanisme Perdagangan Efek Bersifat Ekuitas di Pasar Regular Bursa Efek menegaskan bahwa perdagangan saham syariah sudah dalam ketentuan syariah dimana masih banyak masyarakat mengganggap investasi di pasar modal adalah transaksi judi sehingga dianggap haram atau tidak memenuhi kaidah syariah. Wakaf saham yang notabene berinvestasi di pasar saham syariah berdampak dari pandangan masyarakat tersebut. Sehingga pola pikir masyarakat tersebut mengancam berkurang untuk masyarakat untuk berinvestasi dan berwakaf melalui saham syariah dan menjadi suatu ancaman tersendiri dalam penghimpunan wakaf saham saat ini. Hal tersebut harus dilakukan mengingat hasil Survei Literasi Wakaf yang dilakukan Badan Wakaf Indonesia bahwa Nilai Indeks Literasi Wakaf (ILW) secara Nasional secara keseluruhan hanya mendapatkan skor 50,48 dan termasuk dalam kategori rendah.

\section{SIMPULAN}

Berdasarkan hasil penelitian, maka diperoleh kesimpulan sebagai berikut:

1. Faktor peluang yaitu pangsa pasar modal mempunyai ruang tumbuh lebih besar merupakan faktor yang paling berpengaruh dalam pengumpulan wakaf saham di Indonesia saat ini. Adapun faktor SWOT lain yang berpengaruh berdasarkan faktor kekuatan yaitu kolaborasi antara regulator, lembaga sekuritas dan lembaga nazhir; faktor kelemahan yaitu pemahanan nazhir mengenai wakaf saham yang masih sedikit; dan faktor ancaman yaitu pola pikir tradisional masyarakat tentang wakaf.

2. Strategi SWOT yang paling tepat dalam pengumpulan wakaf saham di Indonesia saat ini adalah Strategi Kelemahan-Kekuatan (Weakness-Opportunity). Pengumpulan wakaf saham 
diupayakan mengungguli faktor kelemahan penghimpunan wakaf dalam mengoptimalkan peluang penghimpunan wakaf saham itu sendiri. Strategi tersebut adalah pembekalan pemahaman lembaga nazhir bukan hanya mengenai wakaf saham, akan tetapi keterampilan dalam berinvestasi syariah melalui saham syariah di pasar modal syariah. Salah satunya adalah memitigasi risiko fluktuasi harga saham dan risiko investasi syariah.

\section{DAFTAR PUSTAKA}

Abdulloh, Irwan. 2019. Pasar Modal Syariab: Sebuah Pengantar Dasar Tentang Pasar Modal Syariah. ed. Aninta Mamoedi. Jakarta: PT. Elex Media Komputindo.

Apriadi, Fiqih, and Muhammad Findi Alexandi. 2013. "Solusi Peningkatan Sumberdaya Manusia Pada Baytul Maal Wat Tamwil (BMT) Di Indonesia Melalui Pendekatan Analytic Network Process (ANP).” Al-Murara'ah 1(2): 107-18.

Aulia, Nur Cahyani, Neneng Hasanah, and Mohammad Iqbal Irfany. 2020. "Strategi Pencegahan Pembiayaan Bermasalah Pada BPRS Di Kabupaten Bogor.” Al-Muzara'Ah 8(1): 73-93.

Ayuniyyah, Qurroh, Abrista Devi, and Tika Kartika. 2019. "The Indonesia Waqf Board (BWI): An Analytical Network Process Analysis." In Revitalization of Waqf for SocioEconomic Development Vol.II, eds. Khalifa Mohamed Ali, M. Kabir Hassan, and Abd elrahman Elzahi Saaid Ali. Switzerland: Springer Nature, 207-28.

Billah, Mohd Ma'sum. 2010. Penerapan Pasar Modal Islam. Selangor: Sweet and Maxwelll Asia.

Dahlan, Rahmat. 2014. "Faktor-Faktor Yang Mempengaruhi Persepsi Nazhir Terhadap Wakaf Uang." Al-Iqtishad 6(2): 307-15.

Fitri, Resfa, and Heni P Wilantoro. 2018. "Analisis Prioritas Solusi Permasalahan Pengelolaan Wakaf Produktif (Studi Kasus Kabupaten Banjarnegara).” Al-Muгara'ah 6(1): 41-59.

Fitriani, Widya Francisca, and Anita Priantina. 2016. "Analisis Penguraian Masalah Pada Program Zakat Produktif.” Al-Muzara'ah 4(2): 142-50.

Fuadi, Nasrul Fahmi Zaki. 2018. "Wakaf Sebagai Instrumen Ekonomi Pembangunan Islam.” Economica: Jurnal Ekonomi Islam 9(1): 151.

Hasim, Khadijah, Deni Lubis, and Khalifah Muhammad Ali. 2016. "Analisis Faktor-Faktor Yang Memengaruhi Penghimpunan Wakaf Uang Di Indonesia (Pendekatan Analytical Network Process)." Al-Můara'Ah 4(2): 127-41.

Haura, Arie, Lukman M Baga, and Hendri Tanjung. 2016. "Analisis Wakaf Uang Pada Koperasi Jasa Keuangan Syariah ( Pendekatan Analytical Network Process)." Jurnal Al Muzara'Ah 3(1): 89-105. 
Iqbal, Muhammad, Prameswara Samofa Nadya, Saripudin Saripudin, and Puji Hadiyati. 2019. "Increasing Community Awareness and Intention in Encouraging The Growth of Cash Waqf." Economica: Jurnal Ekonomi Islam 10(1): 29.

Khairi, Khairil Faizal et al. 2015. "Share Waqf (Corporate Waqf) as an Alternative Financial Instrument in Improving the Communities and Nation Welfare." SSRN Electronic Journal.

Khairil Faizal Khairi et al. 2014. "Human and Economic Development through Share Waqf (Waqf Corporate): The Case of GLCS in Malaysia." Life Science Journal 11(10): 104-10.

Khairunisa, Rizanti, Nashr Akbar, and Abrista Devi. 2017. "Exploring Strategies to Enhance Islamic Banking's Role to Raise Cash Waqf Funds." Iqtishadia: Jurnal Kajian Ekonomi dan Bisnis Islam 10(2): 1-28.

Khairunnisa, Khairunnisa, and Anita Priantina. 2019. "Decomposing Problems in Cash Waqf Fund-Raising in Indonesia." In Revitalization of Waqf for Socio-Economic Development Vol.II, eds. Khalifa Mohamed Ali, M. Kabir Hassan, and Abd elrahman Elzahi Saaid Ali. Switzerland: Springer Nature, 249-68.

M. E. Burhanudin. 2017. "Status Wakaf Saham Pada Emiten Yang Keluar Dari Daftar Efek Syariah (DES)." Al-Awqaf: Jurnal Wakaf Dan Ekonomi Islam 12(1): 72-85.

Mohsin, Magda Ismail A. 2012. "Waqf-Shares: New Product to Finance Old Waqf Properties." Banks and Bank Systems 7(2): 72-78.

Nurdany, Achmad. 2019. "Ensuring the Determinant of Waqf in Indonesia: Does Religiosity Matter?” Jurnal Ekonomi dan Keuangan Islam 5(1): 18-24.

Paksi, Girindra Mega, Asfi Manzilati, and Marlina Ekawaty. 2018. "Kajian Hukum Dan Implementasi Wakaf Harta Bergerak Di Indonesia: Wakaf Uang Dan Saham." Islamiconomic: Jurnal Ekonomi Islam 9(2): 173-90.

Permaisela, Dera. 2019. "Analysis of Productive Waqf Practice and Management: Using Swot Analysis Method." al-Uqud: Journal of Islamic Economics 3(1): 85-97.

Prasetyo, Aji. 2019. "Wakaf Saham Dalam Meningkatkan Investasi Saham Syariah Di Indonesia." Majalah Ekonomi 24(2): 204-10.

Rahman, Muhammad Fudhail. 2009. "Wakaf Dalam Islam.” Al-Iqtishad: Jurnal Ilmu Ekonomi Syariah 1(1).

Rusydiana, Aam Slamet, and Fatin Fadhilah Hasib. 2019. "Islamic Banking Selection Criteria: Case in Indonesia Using Analytic Network Process." Economica: Jurnal Ekonomi Islam 10(1): 165-88.

Saidu, Oluwaseun Sulaiman. 2019. "Highlighting the Links Between Islamic Accounting and the Cash Waqf." International Journal of Islamic Business and Economics (IJIBEC) 3(2): 146- 
55.

Selasi, Dini, and Muzayyanah Muzayyanah. 2020. "Wakaf Saham Sebagai Alternatif Wakaf Produktif Pada Perkembangan Ekonomi Syariah Di Indonesia." Tawazun: Journal of Sharia Economic Law 3(2): 155-70.

Shulthoni, Muhammad, Norma Md Saad, Saim Kayadibi, and Muhammad Irwan Ariffin. 2018. "Waqf Fundraising Management: A Proposal for a Sustainable Finance of the Waqf Institutions." Journal of Islamic Monetary Economics and Finance 3(Speciall Issue): 15378.

Suhaimi, Farhana Mohamad, Asmak Ab Rahman, and Sabitha Marican. 2014. "The Role of Share Waqf in the Socio-Economic Development of the Muslim Community: The Malaysian Experience." Humanomics 30(3): 227-54. http://dx.doi.org/10.1108/H-122012-

0025\%5Cnhttp://dx.doi.org/10.1108/03068290210413038\%5Cnhttp://dx.doi.org/10. 1108/WJEMSD-09-2013-0052.

Tanjung, Hendri, and Abrista Devi. 2013. Metodologi Penelitian Ekonomi Islam. Jakarta: Gramata Publishing.

Thaker, Mohamed Asmy Mohd Thas, and Hassanudin Mohd Thas Thaker. 2015. "Exploring the Contemporary Issues of Corporate Share Waqf Model in Malaysia with the Reference to the Waqaf An-Nur Corporation Berhad.” Jurnal Pengurusan 45(2015): 16572. 